\title{
Irish consequences of the Great War
}

\author{
DAVID FITZPATRICK* \\ Trinity College, Dublin
}

\begin{abstract}
A B STRACT. It is now widely admitted that the Great War was also Ireland's war, with profound consequences for every element of Irish life after 1914. Its impact may be discerned in aberrant aspects of Ireland's demographic, economic and social history, as well as in the more familiar political and military convulsions of the war years. This article surveys recent scholarship, assesses statistical evidence of the war's social and economic impact (both positive and negative), and explores its far-reaching political repercussions. These include the postponement of expected civil conflict, the unexpected occurrence of an unpopular rebellion in 1916, and public response to the consequent coercion. The speculative final section outlines a number of plausible outcomes for Irish history in the absence of war, concluding that no single counterfactual history of a warless Ireland is defensible.
\end{abstract}

$\mathrm{I}$

$\mathrm{t}$ is now widely admitted that the Great War was also Ireland's war, with profound consequences for every element of Irish life after $1914 .{ }^{1}$ Its impact may be discerned in aberrant aspects of Ireland's demographic, economic and social history, as well as in the more familiar political and military convulsions of the war years. The recent flood of publications on Ireland and the Great War has done much to transform 'Ireland's Great War' from an abstraction to a multitudinous human chronicle. In 1986, when the Trinity History Workshop issued its pioneering collection of student essays on the subject, the only available military survey was Henry Harris's tribute to the Irish regiments published in 1968. Today, there are several useful histories of the three Irish divisions, and a shelf of studies documenting individual Irish battalions, often using local sources and personal testimony to embellish the military chronicle based on official war diaries. ${ }^{2}$

* Department of History, Trinity College Dublin, dftzptrk@tcd.ie

${ }^{1}$ David Fitzpatrick (ed.), Ireland and the First World War (Dublin, 1986); Keith Jeffery, Ireland and the Great War (Cambridge, 2000); Adrian Gregory and Senia Pašeta (eds), Ireland and the Great War: 'a war to unite us all?' (Manchester, 2002); John Horne (ed.), Our war: Ireland and the Great War (Dublin, 2008).

${ }^{2}$ Fitzpatrick, Ireland and the First World War; Henry Harris, The Irish regiments in the First World War (Cork, 1968); Tom Johnstone, Orange, green and khaki: the story of the Irish regiments in the Great War, 1914-18 (Dublin, 1992); Terence Denman, 
Through the enthusiasm of a small but expanding band of journalists and historians, we now have access to a chorus of 'forgotten voices' of Irishmen who served, drawing upon interviews, autobiographies, and material collected by institutions such as the Imperial War Museum. These 'Irish' stories include accounts of cowardice as well as heroism, dogged survival as well as high ideals. Whereas stories of heroism were once predominant, many current writers picture their subjects as passive victims of a futile conflict, helpless in the face of an intractable war machine. ${ }^{3}$ Doubtless, as in British and Australian accounts of the Great War, tales of survivorship and resourcefulness will eventually displace those of victimhood. The problem with assembling forgotten 'Irish' voices, as with writing histories of 'Irish' units, is the difficulty of extracting what is distinctively Irish. The 'Irish' divisions were never purely Irish and became less so. Most Irish servicemen spent much of their war in a cosmopolitan environment, living and fighting among men of many nationalities, and undergoing shared privations and challenges. Neither war diaries nor anthologies of personal testimony, no matter how engrossing, reveal much about Ireland's war in particular.

Aided by digital access to official compilations such as Soldiers died in the Great War and the records of the Imperial (Commonwealth) War Graves Commission, rolls of honour for individual counties and towns have also mushroomed. Most belong unashamedly to the 'contribution' school of war history, any local link (however tenuous) justifying enlistment in the celebratory catalogue of 'Dubliners' or 'Mayomen' who died or fought for whatever it was. Some politicians (and historians who should know better) believe that, once every county has its roll of honour, it will be possible to aggregate the county figures and produce a new, perhaps even more multitudinous edition of Ireland's memorial records, conceivably dragging the number of Irish dead beyond the 50,000 line. ${ }^{4}$ Such fantasies ignore the inevitable duplication and inconsistency of criteria exhibited by these labours of love and piety. It remains essential to distinguish clearly between those who came out of fractured Ireland to serve, and those with Irish birth or ancestry who were drawn into the war (under very different pressures and agencies) in Britain, the dominions, or the United States.

The most crippling deficiency in current scholarship is surely the absence of systematic, statistical analysis of the social and economic impact of the war in Ireland. Since Marwick and others opened up the terrain of 'total war' in the 1960s, explorers of the 'home front' in Britain, the dominions, and Europe have uncovered unexpectedly positive domestic consequences for the

Ireland's unknown soldiers: the 16th (Irish) division in the Great War, 1914-1918 (Dublin, 1992); Philip Orr, The road to the Somme: men of the Ulster division tell their story (Belfast, 1987); Philip Orr, Field of bones: an Irish division at Gallipoli (Dublin, 2006); Stephen Sandford, Neither unionist nor nationalist: the 10th (Irish) division in the Great War, 1914-1918 (Dublin, 2014).

${ }^{3}$ See, for example, Myles Dungan, They shall not grow old: Irish soldiers and the Great War (Dublin, 1997); Neil Richardson, A coward if I return, a hero if I fall: stories of Irishmen in World War I (Dublin, 2010); Kevin Myers, Ireland's Great War (Dublin, 2014); Turtle Bunbury, The glorious madness: tales of the Irish and the Great War (Dublin, 2014).

${ }^{4}$ Committee of the Irish National War Memorial, Ireland's memorial records, 1914-1918: being the names of Irishmen who fell in the Great European War, 1914-1918, (8 vols, Dublin, 1923). 
economy, for women, and for social inequality. ${ }^{5}$ Such findings have provoked strong reactions, citing the war's negative effects for fractured families, overworked women, and choice-starved consumers. In Ireland, the evidence for an informed debate remains largely untapped. We know that the war created an unprecedented boom in agriculture, while worsening living conditions for many urban workers. Yet the scale and relative force of these two processes have yet to be properly measured, making it impossible to place the Irish case in comparative context. So far, we have been content with observing that the war's impact on workers, women, and consumers in Ireland was in most respects a muffled echo of its impact in Britain. The next section aims to offer a preliminary but more precise assessment of its social and economic consequences for Ireland.

The most serious demographic consequence was to increase the mortality of younger adult males by at least 30,000 , so doubling the number of such deaths recorded in an equivalent period of peace. ${ }^{6}$ The removal of over 200,000 servicemen from the home population, for all or part of the war period, had the further effect of restricting sexual intercourse, though the frequency of marriages was unabated. The outcome was a reduction of fertility by one part in nine (a proportion far smaller than in Britain or most other combatant countries). Emigration, long endemic in Ireland's ever-declining population, was temporarily curtailed by the disruption of passenger shipping, the submarine campaign, and reduced demand for immigrant labour in the

${ }^{5}$ For thematic surveys, see Jay Winter (ed.), The Cambridge history of the First World War (3 vols, Cambridge, 2014), iii, Civil society.

6 According to the Registrar-General for Ireland, 27,405 Irish servicemen (excluding officers) died on active service outside the United Kingdom between 1914 and 1918 . The true number of deaths attributable to war service, excluding those of 'Irish' servicemen enlisted outside Ireland, probably exceeded 30,000. In the decade 1901-10, 64,364 men aged 20-44 were registered as having died in Ireland, equivalent to 27,355 deaths of men of roughly military age over a period of 4.25 years (as between August 1914 and November 1918). The war had no clear consequences for domestic mortality within Ireland, the number of registered deaths being 294,250 for 1910-13 and 298,961 for 1915-18. See Saorstát Éireann, Census of population, 1926, x, General report (Dublin, 1934), p. 12; Supplement to the 47th report of the Registrar-General of Marriages, Births, and Deaths, in Ireland, containing decennial summaries . . for the years 1901-1910, in House of Commons Papers [HCP], 1914 [Cd 7121], xv, 1; W. E. Vaughan and A. J. Fitzpatrick (eds), Irish historical statistics: population, 1921-1971 (Dublin, 1978), Table 45.

7 The number of births registered in Ireland, 1915-18, fell below the figure for 1910-13 by $44,156(11 \%)$. The equivalent reductions elsewhere were $14 \%$ in Scotland, $17 \%$ in England and Wales, $25 \%$ in Italy, $42 \%$ in both France and Belgium, $43 \%$ in Germany, and $48 \%$ in Hungary. Fertility remained low in 1919, preceding the 'baby boom' of 1920. In contrast with the wartime decline in nuptiality in continental Europe, the number of marriages scarcely changed in Ireland and Britain, apart from an eruption of 'war marriages' peaking in 1915. Figures are derived from Vaughan and Fitzpatrick, Irish historical statistics, Tables 43, 44; B. R. Mitchell, European historical statistics, 1750-1975 (London, 1987 edn), Table B5. 
United States and most other Irish destinations. ${ }^{8}$ The decline in 'permanent' emigration was outweighed, however, by the migration of Irish servicemen towards the front and of Irish munition workers to Britain. ${ }^{9}$ It was only in Connaught and the western seaboard, where pre-war emigration had been most intense, that the stoppage of emigration eventually exceeded the depletion due to military enlistment. The aggregate demographic impact of Ireland's war was therefore negative, amounting to 30,000 war-related deaths, 50,000 averted births, and a fluctuating but substantial increase in temporary movement out of Ireland.

The war's economic consequences for Ireland were only partly determined by the drastic reduction in the male labour force, which was most marked in Ulster and in urban areas. The contraction of labour supply was to some extent negated by the wartime reorganisation of production, leading to massive redeployment of labour in munitions and to the disruption or stagnation of sectors considered inessential to 'the war effort'. The number of insured Irish workers in engineering rose by a quarter between July 1914 and July 1918, whereas employment in building and construction declined by a tenth. ${ }^{10}$ In Dublin, unlike most major cities in Britain and Ireland, the wartime expansion of heavy industrial production was insufficient to counteract the recession in the city's staple trades, such as building, clothing, and retailing. The net effect of disrupting normal trade, while also depleting the workforce through moderate enlistment, was therefore to maintain unemployment close to the unacceptably high levels recorded in Dublin before the war. ${ }^{11} \mathrm{By}$ contrast, labour became scarce in Belfast and much of the north-east, where heavy enlistment coincided with successful adaptation of the engineering, shipbuilding, and textile trades to specialised military, naval, and aeronautical requirements. Belfast and the northern district accounted for over four-fifths of the workforce in Irish munition factories and military establishments in January $1916 .{ }^{12}$ By the end of 1917 , Irish unemployment had fallen to $1.5 \%$ of the insured workforce in ship-building and $2.4 \%$ in engineering, but remained considerable in printing (4.6\%) and in building and construction (4.9\%). In Britain, where the workforce had been depleted by conscription as well as heavier voluntary enlistment, less than one worker in a hundred was out of work in each of these industries. ${ }^{13}$ Whereas industrial unemployment virtually

8 The Registrar-General recorded the emigration of only 21,052 persons from Irish ports for 1915-18, compared with 123,341 for 1910-13 (a reduction of 83\%): Vaughan and Fitzpatrick, Irish historical statistics, Table 54.

9 Over 34,000 workers were engaged by British munition factories through Irish labour exchanges in 1917-18: Neil O'Flanagan, 'Dublin City in an age of war and revolution, 1914-1924' (M.A. thesis, University College, Dublin, 1985), p. 47.

${ }^{10}$ In ship-building, the increase was $14 \%$. Employment in these sectors declined markedly in the first half of the war, recovering between 1916 and 1918: monthly official returns in the Board of Trade Labour Gazette (subsequently issued by the Ministry of Labour).

${ }^{11}$ O'Flanagan, 'Dublin City', p. 9; E. J. Riordan, Modern Irish trade and industry (London, 1920), ch. 11. For a bleak account of Dublin's wartime economy, see Padraig Yeates, A city in wartime: Dublin, 1914-18 (Dublin, 2011).

12 Brennan Papers, N.L.I. MS 26191.

13 On 30 June 1914, the proportions unemployed in Ireland were $4.5 \%$ in shipbuilding, $4.9 \%$ in engineering, $4.4 \%$ in printing, and $7.0 \%$ in building and construction (corresponding figures for the entire United Kingdom being 4.1\%, 3.3\%, 3.2\%, and 
disappeared in wartime Britain, it was merely reduced in the case of Ireland. It is therefore not surprising that the increase in Irish industrial wages failed to keep pace with inflation between 1913 and 1920, though the differential was small. ${ }^{14}$

If the net impact of the war on the demand for Irish urban labour was inconsistent, its consequences for agriculture were incontestable. Irish farming prospered during the disruption of international trade, which virtually eliminated competition from European imports and sharply reduced the volume of food imports from America and Australasia. Irish farmers cannily exploited their comparative advantage of proximity to the British market, investing heavily in fodder, seeds, and improved equipment in order to maximise their returns as agricultural prices soared. Between 1912 and 1917, advanced 'agricultural machines' multiplied in Ireland as in Britain, while the population of basic ploughs, harrows, mowers, and threshers scarcely changed. ${ }^{15}$ Prices for livestock and farm products generally rose faster than the cost of living. By 1918, Irish prices for wheat, butter, and pork exceeded those in 1913 by up to $140 \%{ }^{16}$ Prices for livestock such as store cattle and fat

$3.8 \%$, respectively). Statistics, from the Labour Gazette, are based on the number of unemployment books lodged compulsorily at labour exchanges or unemployment fund offices, the number insured being estimated annually as in July. Returns of unemployment in printing were supplied by the trades unions.

${ }^{14}$ Aggregate official wage returns were not compiled for Ireland during the war years, but comparison is possible between October 1913 and December 1920. The increases in various trades (expressed as unweighted means of the increases in all Irish towns for which figures were returned in both years) were as follows. Engineering: 177\% (turners), 175\% (fitters), 173\% (pattern-makers). Metals: 143\% (iron-founders), 136\% (shipwrights), 106\% (ship-joiners). Building: 177\% (brick-layers), 172\% (masons), 175\% (carpenters and joiners), 170\% (plumbers), 180\% (plasterers), 181\% (painters), 301\% (labourers). Miscellaneous: 191\% (cabinet-makers), 179\% (compositors), 162\% (boot and shoe-makers), $187 \%$ (bakers). Most of these wage increases fall somewhat short of inflation, as measured by the Sauerbeck-Statist index which indicated an increase of 195\% in wholesale prices in the United Kingdom between 1913 and 1920. See Standard time rates of wages in the United Kingdom at 1st October, 1913, in HCP, 1914, 1xxx [Cd. 7194], 919; Standard time rates of wages and hours of labour in the United Kingdom at 31st December, 1920, in HCP, 1921, xl [Cmd. 1253], 711; B. R. Mitchell and Phyllis Deane, Abstract of British historical statistics (Cambridge, 1971 edn), pp 474-5.

15 For every 100 machines and implements enumerated in Ireland in 1912, the number in 1917 (in descending rank order) was as follows: multi-furrow ploughs 296, combined threshers and finishers 222 , disc harrows 217 , steam engines 179 , spring-tooth harrows 174, potato-diggers 158 , binders 157 , water wheels and turbines 139 , horse potato-sprayers 123 , knapsack potato-sprayers 117 , single-furrow ploughs 115 , mowers and reapers 112, ordinary fixed-tooth harrows 101, winnowers and fanners 101, ordinary threshers 93, seed-sowing machines for turnips and mangels 93: Department of Agriculture and Technical Instruction for Ireland [D.A.T.I.I.], Agricultural statistics, Ireland 1912: reports and tables relating to Irish agricultural labourers, 42-5, in HCP, 1913, lxxvi [Cd. 6928], 469; Saorstát Éireann, Department of Industry and Commerce, Agricultural statistics, 1847-1926 (Dublin, 1928), pp 150-3. No statistics for intervening years have been located.

16 The percentage ratio of annual average wholesale prices in 1918 to those in 1913 was 227 for wheat, 230 for butter, and 240 for pork, but only 146 for potatoes (destined mainly for the domestic market): figures adapted from Thomas Barrington's calculations in 'A review of Irish agricultural prices' in Stat. Soc. Ire. Jn., xiv (1925-6), pp 249-80, at p. 253. 
pigs rose steadily throughout the war, as did the demand for white oats and (less steadily) for other crops. The only exception was the price of potatoes, destined mainly for domestic consumption, which rose by only $46 \%$ between 1913 and 1918, but fluctuated sharply in response to variations in yield caused by blight or weather. The acute shortage of potatoes during the severe winter of 1916-17 had severe but temporary consequences for urban workers, counteracted to some extent by relief bodies sponsored by the government, philanthropists, and Sinn Féin. ${ }^{17}$

Otherwise, agricultural production flourished to a degree unknown since the Napoleonic wars. ${ }^{18}$ The particular shortage of grain gave rise to regulations for the compulsory extension of tillage, which met with only feeble opposition because of the economic incentive to act on them. ${ }^{19}$ The area under cultivation increased by 39 per cent between 1914 and 1918, compared with only 19 per cent in Britain. ${ }^{20}$ Extra cultivation required extra farm labour, and in regions not swamped by surplus farmers' sons, thwarted in their desire to emigrate, shortages of skilled workers such as ploughmen were reported. The economic impact of the war was on balance positive. Despite stagnation in towns such as Dublin and continued under-employment in the rural west, the Irish economy did surprisingly well out of the war.

The wartime reorganisation of the economy had pronounced, if temporary, consequences for Irish society, creating greater demand for the services of hitherto subsidiary elements such as farm labourers and women. After more than half a century of declining demand for hired workers in agriculture, their bargaining power was momentarily enhanced by the revival of tillage. In 1918-20, for the first time since the 1870s, farm workers began to assert their collective interest by joining trades unions, a process which ended in anticlimax with the abandonment of confrontation between the 'Red Guards' and the 'Farmers' Freedom Force' in summer 1920. ${ }^{21}$ The expansion of industrial action and unionisation affected almost all sectors of the labour force, becoming marked in 1917-18 as the cumulative impact of wartime labour shortages intensified. The growth of trades unionism was a rational response to reduced unemployment, which rendered it more difficult for employers to recruit substitutes for protesting employees. Irish workers responded more vigorously than their British brethren to their improved bargaining position, being less inhibited by statutory regulation and the voluntary suspension of

17 Average Irish potato prices for each quarter (1913-18), in pence per hundredweight, were as follows: 1913: 47, 53, 51, 34; 1914: 36, 39, 49, 38; 1915: 50, 52, 47, 44; 1916: 41, 59, 81, 98; 1917: 116, 133, 80, 64; 1918: 52, 63, 79, 74: D.A.T.I.I., Journal, passim.

${ }_{18}$ For long-term trends in Irish agriculture, see Saorstát Éireann, Department of Industry and Commerce, Agricultural statistics, 1847-1926 (Dublin, 1928); Michael Turner, After the Famine: Irish agriculture, 1850-1914 (Cambridge, 1996); Cormac Ó Gráda, Ireland: a new economic history, 1780-1939 (Oxford, 1994).

19 By early 1917, 4,006 farmers (less than 2\% of rateable occupiers in Ireland) had sought exemption from the regulations, leading to 865 grants, while 8-9,000 failures to implement the regulations had been reported: D.A.T.I.I., Journal, xvii (Apr. 1917), pp 507-10.

20 Annual Agricultural statistics of Ireland, in H.C.P.; Ministry of Agriculture, A century of agricultural statistics: Great Britain, 1866-1966 (London, 1968), Table 43.

21 David Fitzpatrick, Politics and Irish life, 1913-1921: provincial experience of war and revolution (Dublin, 1977), pp 272-3. 
collective action by the great British 'amalgamated' unions that had signed the Treasury Agreements of 1915. The growth of Irish trades unionism is thus attributable, at least in part, to the economics of war, as workers exploited diminished unemployment to claim a share in the buoyant economy of the war and its immediate aftermath. ${ }^{22}$

The same logic applied, if less forcefully, to women, whose progressive withdrawal from many sectors of the paid workforce had been a feature of 'post-Famine adjustment'. ${ }^{23}$ Though less insistently than in Britain, women in Ireland were called upon to substitute for unavailable male workers in many novel sectors of production. Practical feminism was embodied by those who migrated temporarily to British munition factories recruiting through Irish labour exchanges. Female membership in trades unions expanded in Ireland as in Britain, and all-female bodies such as the Irish Women Workers' Union flourished in wartime having struggled for survival before 1914. By 1917, nearly 17,000 women were returned as members of thirteen Irish-based unions, treble the number for the previous year. ${ }^{24}$ Aggregate returns are unavailable thereafter, but the unionisation of women undoubtedly accelerated between 1917 and $1919 .^{25}$ The recent eruption of Irish interest in women's history has yet to deliver a scholarly synthesis for this crucial period, and the extent of female infiltration of the wartime economy remains uncertain. ${ }^{26}$

The economic and social consequences of the war lingered long after the armistice, helping to shape the revolution and civil wars that followed. The closure of war industries led to severe but often temporary unemployment even before the phased return of over 100,000 ex-servicemen: 94,000 Irish workers were receiving the emergency out-of-work donation by the end of February $1919 .^{27}$ As work resumed in 'normal' industrial sectors such as building and

22 David Fitzpatrick, 'Strikes in Ireland, 1914-1921' in Saothar, vi (1980), pp 26-39; see also Theresa Moriarty, 'Work, warfare and wages: industrial controls and Irish trade unionism in the First World War' in Gregory and Pašeta, Ireland and the Great War, pp 73-93; Niamh Purcell, 'War, work and labour' in Horne, Our war, pp 181-194.

23 Joanna Bourke, Husbandry to housewifery: women, economic change, and housework in Ireland, 1890-1914 (Oxford, 1993), part I.

${ }^{24}$ Incomplete returns give the number of women belonging to Irish trades unions as 4,391 in 1914, 4,428 in 1915, 4,900 in 1916, and 14,651 in 1917 (excluding the I.W.W.U.). Many Irish workers would have belonged to other unions, without Irish placenames or the word 'Irish' in their titles. See Ministry of Reconstruction, Report of the women's employment committee, pp 94-106, in HCP, 1918 [Cd 9239], xiv, 783.

${ }^{25}$ Membership of the I.W.W.U. (only 'a few hundreds' at the end of 1916) was returned as 2,300 in 1917, 5,300 in 1918, 5,400 in 1919, and 2,942 in 1920. Female membership of the Irish Drapers' Assistants' Association rose only slowly from 1912 $(1,309)$ through $1914(1,413)$ to $1917(1,471)$, thereafter increasing to 1,898 in 1918 , 2,933 in 1919, and 3,028 in 1920. The strength of the Dublin Guild of Female Biscuit Operatives increased from 894 to 1,255 during its first year (1916), subsequently subsiding to 1,190 in 1917, 1,183 in 1918, 1,106 in 1919, and 1,079 in 1920. See Liza Marie Toye, 'Women workers in Dublin during the First World War' (M.Litt. thesis, Trinity College, Dublin, 1989), pp 96, 102, 150.

${ }^{26}$ See, however, Catriona Clear, 'Fewer ladies, more women' in Horne, Our war, pp $157-70$.

27 The donation was soon limited to ex-servicemen and civilians in 'insured' trades, who ceased to be eligible from Nov. 1919; the scope of the dole for uninsured civilians was much reduced after Feb. 1919. By 28 Feb., donations for uninsured workers had been issued to 42,214 men, 2,034 boys, 30,236 women, and 2,836 girls, in addition to 
construction, the problem was alleviated, though many ex-servicemen found it impossible to get work in competition with those who had stayed at home. In November $1919,46 \%$ of veterans who had returned to Ireland were receiving the donation. ${ }^{28}$ Unemployment again became a serious problem in the second half of 1920, as the agricultural boom finally collapsed with the resumption of international trade (the price of wheat, butter, and pork fell by about one-third between 1921 and 1922). ${ }^{29}$ The number registered for employment at Irish labour exchanges rose from 58,000 at the end of 1920 to 84,000 only a month later, and 113,000 by the end of $1921 .^{30}$ The onset of depression in 1921 ensured that labour's bargaining power was much greater during the AngloIrish conflict than the subsequent civil wars, making class a less significant factor in the later phases of unrest despite the dreams of Liam Mellows and Roddy Connolly. Likewise, the collapse of international demand for Irish farm produce, while increasing rural grievances, made it less feasible to organise effective combinations of farm workers or land-hungry small holders. It seems astonishing that, even today, most historians of Ireland's revolution and civil wars ignore the changing economic context within which these occurred. Equally odd is the reluctance of economic historians to incorporate wars and revolutions in time series and regressions: such 'blips' appear, if at all, as impenetrable dummy variables.

The impact of the war on political change is less straightforward, because of the complex spiral of protest, coercion, and counter-violence which followed the seemingly independent shock of the Easter Rising. The immediate political effect of the outbreak of war was to initiate a sequence of manoeuvres and commitments culminating in the formal enactment and suspension of Home Rule for all Ireland on 18 September 1914. This was accompanied by Asquith's undertaking that, before implementation, the Government of Ireland Act would be amended in the hope of placating Ulster unionists. The participation of both unionists and Home Rulers in the wartime 'party truce' transformed the relationship of each party with the British government, if not with each other. Redmond's immediate approbation of the declaration of war on Germany, and his subsequent advocacy of unrestricted nationalist participation, allied his party's interests as never before with Asquith's Liberal government and Birrell's administration in Dublin Castle. Though Redmond declined to become Chief Secretary in the first coalition government, the Irish Parliamentary Party was sucked into policy-making through regular secret meetings between party leaders and the Castle executive. Birrell redefined

17,003 sailors and 14 women in the forces (no soldiers were yet in receipt). Over the four weeks to $28 \mathrm{Feb}$., the average number of insured workers receiving benefits was 51,315 civilians and 8,660 demobilised servicemen. Thereafter, the published statistics were not broken down by regions such as Ireland: Labour Gazette (Jan.-Mar. 1919).

28 Jane Leonard, 'Survivors' in Horne, Our war, pp 209-23, at p. 216.

29 Annual index prices for wheat, butter, and pork $(1913=100)$ in $1918-21$ were as follows: wheat: 227, 227, 286, 206; butter: 230, 273, 310, 200; pork: 240, 247, 294, 202 : for source, see n. 16, above.

${ }^{30}$ Fitzpatrick, Politics and Irish life, p. 253. 
himself as caretaker for the post-war Home Rule ministry over which Redmond was expected to preside.

Ulster unionists, who had been far more disaffected than the Home Rulers from Asquith's peacetime government, were even more thoroughly integrated into the process of wartime government. Once Carson had affirmed unqualified support for the participation of Ulster unionists in the war effort, in exchange for the formation of an army division (the 36th) formed directly from the Ulster Volunteer Force, his pre-war threats of a coup d'état and secession from the United Kingdom were quickly forgiven. ${ }^{31}$ Unlike Redmond, he agreed to serve in the first coalition government, taking full advantage of the growing dominance of unionists within the coalition even before Lloyd George's assumption of power in December 1916. Though still bitterly at odds with Birrell's Dublin Castle, the Ulster unionists exploited their connections in Westminster and Whitehall to interfere ever more effectively in Irish policy-making and patronage. Since nationalist and unionist interests remained unreconciled, the entanglement of both parties in government led on occasion to bitter collisions, most notably in early 1916 when a series of senior administrative and judicial appointments demonstrated the stronger influence of the 'Orange' interest. ${ }^{32}$ Nevertheless, the common experience of both rhetorical and practical commitment to the war effort gradually diminished mutual distrust, as Redmond had anticipated. The net effect of the war until April 1916 was to bring two potentially rebellious Irish parties into Westminster's fold, and to increase the possibility of a negotiated post-war settlement. $^{33}$

Contrary to the prediction of many separatists, deluded by Wolfe Tone's equation of England's war with Ireland's opportunity, the outbreak of the war failed to stimulate disenchantment with Home Rule or desire for rebellion. Initially, indeed, the reverse seemed to apply. Less than a tenth of the 190,000 Irish National Volunteers repudiated Redmond's leadership when the republican-controlled Provisional Committee denounced his advocacy of overseas service in late September 1914. Most radical nationalist bodies, including the Gaelic League, the Gaelic Athletic Association, Sinn Féin, and the Irish Transport and General Workers' Union, declined sharply in practical activity after August 1914. The Irish Republican Brotherhood was unique in achieving significant gains in money and muscle, but its membership remained tiny by comparison with an enrolment of 20,000 or more in the $1880 \mathrm{~s}^{34}$ Birrell's administration adeptly avoided measures likely to provoke resurgence of popular support for radical nationalism, showing surprising mildness (by both Irish and wartime standards) in applying the draconian Defence of

31 For a sceptical account of the U.V.F.'s contribution to the Ulster Division, see Timothy Bowman, Carson's army: the Ulster Volunteer Force, 1910-22 (Manchester, 2007).

32 See, for example, Leon Ó Broin, The Chief Secretary: Augustine Birrell in Ireland (London, 1969), ch. 5.

${ }^{33}$ See Paul Bew, Ideology and the Irish question: Ulster unionism and Irish nationalism, 1912-1916 (Oxford, 1994), ch. 6.

${ }^{34}$ Returns from divisional centres indicated that the number of paying members within Ireland was 1,660 in 1912 and about 2,000 in 1914: Seán Cronin, The McGarrity papers (Tralee, 1972), pp 32-3; Diarmuid Lynch, The I.R.B. and the 1916 Rising, ed. Florence O’Donoghue (Cork, 1967), p. 24. 
the Realm regulations. Though MacNeill's Irish Volunteers were ever more bellicose and extreme in their anti-war demonstrations, these were widely regarded as the ravings of an unpopular fringe group posing no immediate threat to the pro-war consensus. Sustained by rural prosperity and complacency as well as political logic, that consensus seemed impervious to the archaic rhetoric of separatists harking back to 1867, 1848, and 1798 .

Admittedly, the declining activity of many elements of radical nationalism was more than matched by the ossification of most of the networks of local organisations which had proved so efficient in mobilising Home Rulers before 1914. Only Joseph Devlin's Ancient Order of Hibernians, which administered national insurance benefits for a vast and growing body of insured workers, remained active throughout the war. ${ }^{35}$ Yet organisational inactivity did not imply popular abandonment of the belief that political freedom was best pursued through parliamentary pressure culminating in a legislative measure granting partial autonomy. The conventional nationalist bodies became quiescent because the war undermined their day-to-day rationale. The party truce virtually eliminated the need to prepare for elections; curtailment of funds for land purchase left the United Irish League without a focus for agrarian agitation; and the suspension of the 'Orange menace' reduced the urgency for defensive alliance among Catholics. Yet the persistent power of the 'parliamentarians' to influence ordinary nationalists was demonstrated by the service of 32,000 National Volunteers in the forces, ${ }^{36}$ by the almost universal if tepid support of the nationalist press for Redmond's strategy, and by the failure of rival organisations and leaders to attract a popular following. Popular acquiescence in Irish collaboration with the British war effort seemed the clearest confirmation of Hyde's gloomy diagnosis in 1892 that the Irish had become Anglicized almost beyond recovery. ${ }^{37}$

From this viewpoint, the Easter Rising may be interpreted as an unpredictable but explicable outcome of radical frustration, rather than the culmination of a prolonged process of radicalisation. Disappointed in their expectation that Irish nationalists would repudiate Redmondism when called upon to risk their lives and livelihood in support of 'England's war', radicals searched for some other external shock capable of unleashing the repressed resentment against English rule which was assumed to lurk beneath Ireland's Anglicized veneer. This interpretation is confirmed by the composition of the loose alliance which the 'Military Council' of the I.R.B. managed to mobilise in Easter Week. By early 1916, the dissident Irish Volunteers were aligned with James Connolly and the rump of his Irish Citizen Army, in seemingly terminal decline after the collapse of the pre-war General Strike and the subsequent enlistment of thousands of trades unionists into the British army. These fragmentary forces were joined by the Hibernian Rifles, organised by the minuscule Irish-American Alliance opposed to Devlin's Board of Erin. It is significant that no radical body was fully committed to participation in a

35 David Fitzpatrick, 'The geography of Irish nationalism, 1910-1921' in Past and Present, no. 78 (1978), pp 113-44, at p. 130.

36 David Fitzpatrick, 'The logic of collective sacrifice: Ireland and the British army, 1914-1918' in Historical Journal, xxxviii (1995), pp 1017-30, at pp 1028-9.

37 Hyde's celebrated address, 'The necessity for de-anglicising Ireland', was presented to the National Literary Society on 25 Nov. 1892, and published in The revival of Irish literature: addresses (London, 1894), pp 116-61. 
Rising, involvement being confined to an élite of trusted activists within each organisation, often without the knowledge of its ostensible leaders. ${ }^{38}$ The Rising was repudiated by the Chief of Staff of the Irish Volunteers (Eoin MacNeill), and planned without reference to the 'President of the Irish Republic' and of the I.R.B.'s Supreme Council (Denis McCullough). The involvement of about 200 members of the Irish Citizen Army, only a minority of whom belonged to Connolly's I.T.G.W.U., did not signify endorsement of the Rising by any representative Labour organisation. ${ }^{39}$ The rationale for reliance on a clandestine élite is obvious: few men or women in wartime Ireland, even separatists of undoubted radicalism and hostility to British rule, could be expected to perform the required leap of imagination. In devising a policy which ignored the conscious preferences of the great majority of contemporary nationalists, while seeking to shock a complacent population into rebelliousness, Pearse, Plunkett, MacDermott, and Connolly displayed the ingenuity of desperate and disappointed men.

In order to mobilise support beyond the charmed circle of dreamers, the leaders employed a variety of stratagems. These included forgery of additional passages in a 'Castle document' envisaging the arrest of all Sinn Féiners and a blockade of the archbishop's palace in Drumcondra; concoction of a bogus plan for a nationwide Rising designed to reassure provincial Volunteers that military victory was both intended and possible; and disingenuous assurances to their Irish-American funders that no Rising would be attempted without extensive military support from Germany. The true logic of the Rising was implicit in the selection of sites to be occupied and defended against the anticipated assault of the 'Crown forces'. Instead of maximising administrative disruption by securing the almost undefended Dublin Castle, Custom House, Telegraph Office, Central Telephone Exchange, and Central Sorting Office, the rebels set up headquarters in an unimportant but exposed building in Dublin's main thoroughfare and shopping district (the General Post Office). Instead of occupying the stoutly walled and logistically invaluable campus of Trinity College, they invited lethal sniping by seizing the indefensible St Stephen's Green. This admittedly circumstantial evidence suggests that their choice of locations was calculated to maximise not military advantage but destruction of property and danger to civilians, since such occupations were almost certain to provoke artillery attacks in areas crowded with shoppers, workers and commuters. ${ }^{40}$ The majority of casualties were not combatants but civilians caught in crossfire. The Crown forces obligingly wrecked much of the city, the political damage being magnified by the arrest and internment of thousands of reputed radicals uninvolved in the Rising. General Maxwell's renewal of sometimes indiscriminate coercion under martial law negated Birrell's remarkably effective policy of appeasement, intensifying the uncontrollable cycle of violence and counter-violence which was eventually to unravel the delicately stitched Anglo-Irish accord of

38 F. X. Martin, 'The 1916 Rising: a coup d'état or a "bloody protest"?' in Studia Hib., viii (1968), pp 106-37.

39 John W. Boyle, 'Irish labour and the Rising' in Éire-Ireland, ii (1967), pp 122-31.

40 This interpretation is not endorsed by Charles Townshend, Easter 1916: the Irish rebellion (London, 2005), esp. pp 353-4, or Fearghal McGarry, 'Violence and the Easter Rising' in David Fitzpatrick (ed.), Terror in Ireland, 1916-1923 (Dublin, 2012), pp 39-57, at pp 42-3. 
September 1914. It follows that the descent into revolution, being a product of the Rising, was ultimately a by-product of the war that had generated the frustration without which no Rising would have been attempted.

Even without the seldom predicted and indeed unpredictable Easter drama, the militarisation of government might eventually have generated serious disaffection and conflict in Ireland. Wartime interference with such civil liberties as habeas corpus, trial by jury, free association, and uncensored expression, always threatened to provoke popular resistance and to radicalise nationalism. Yet, as the British example showed, most of the warring powers proved capable of maintaining popular support despite curtailments of liberty which would have provoked furious protest in peacetime. This was attributable not merely to adept control of public opinion through propaganda and the press, but more profoundly to widespread acceptance by individuals of the need for shared 'sacrifice' in wartime. Even in Ireland, as Birrell had demonstrated, a policy of moderate and selective coercion could achieve popular acquiescence. The temporary relapse into arbitrary and excessive coercion under Maxwell illustrated the disastrous consequences of allowing military methods to supplant political logic in civil affairs. Maxwell's error was repeated at intervals between 1917 and 1921, as the attempt to maintain the rule of law was progressively abandoned in face of republican defiance.

The most counter-productive military initiative after 1916 was the aborted attempt to impose conscription two years later, in response to the War Office's panic-driven demand for reinforcements during the German spring offensive. Though eventually abandoned when military as well as political analysts realised that fewer men would be enlisted than would be required to enlist them, the threat of conscription through Order in Council (under the Military Service (No. 2) Act of March 1918) instantly united the still fractured forces of Irish nationalism, thereby eliminating constitutionalism as a practical alternative to separatism. Whereas the outbreak of war had reconciled Irish nationalists with Britain as never before, the threat of conscription caused alienation on a scale unknown since the 1880s. The Great War was indeed the major determinant of Irish political change between 1914 and $1918 .{ }^{41}$

\section{IV}

\section{But louder sang that ghost, 'What then?'42}

No attempt to classify the Irish consequences of the Great War could, in itself, establish the most likely course of events in the absence of such a war. Parallel analysis is required of the cumulative consequences of persistent international peace between 1914 and 1918. Such conjectures must rest on the assumption that all factors and trends apparent in August 1914 would have

41 After 1918, the Great War continued to shape Irish politics. Sinn Féin's campaign for international recognition was based on the commitment of the allied powers to selfdetermination for small nations; the return of over 100,000 servicemen posed a challenge to the republican consensus as well as supplying personnel for all military, paramilitary, and political forces; and war commemoration has recently become a significant element of the northern 'peace process'.

${ }_{2}$ W. B. Yeats, 'What then?', published posthumously in Last poems and plays (London, 1940). 
remained in force thereafter, but for the disruptive outbreak of war. This assumption, unavoidable in counterfactual history, disregards the possible intrusion of other unforeseen 'shocks' which, like the Rising or the war itself, might at any moment have upset predictions based on the best-informed analysis of Irish economic, social, or political organisation. Unpredictable shocks which fail to materialise lie beyond history, even beyond informed speculation. Furthermore, extrapolation from pre-existing factors and trends typically points to a range of possible outcomes, creating unmanageable complications after a couple of links in the causal chain. What follows is not a defensible alternative history of a warless Ireland after 1914, but an attempt to lend plausibility to several alternative histories.

If pre-war demographic patterns had persisted, an extra 100,000 men and women would have left Ireland between 1915 and 1918 with the intention of 'permanent' settlement overseas. This predominantly rural exodus must be set against the 250,000 servicemen and munition workers whose 'temporary' departure from mostly urban areas would not have occurred but for the war. ${ }^{43}$ The accumulation of a restive surplus of under-employed westerners would have been alleviated, but unemployment in Irish cities would have remained dangerously high. To the extent that demographic influences on labour supply determine social conflict, the absence of war would therefore have encouraged urban unrest while defusing rural unrest. Yet this contrast dissolves if the counterfactual analysis is extended from demography to economics. Without a war, Irish farmers would have found it increasingly difficult to compete in the British market with cheap imports such as Canadian store-cattle, and the agricultural sector might have experienced recession rather than boom. The extent to which emigration would have cushioned such a decline in Irish agriculture is obscure, being governed by the ever-fluctuating demand for imported workers in many parts of the globe. By contrast, there is no clear reason to doubt that Ulster's trade in textiles, ships, and engineering products would have continued to flourish at the expense of its Scottish and English competitors. If so, the economic gulf between northern and southern Ireland would have been exacerbated.

In the absence of war, and the consequent persistence of heavier urban unemployment, the bargaining position of Irish workers would have remained weaker than in a warless Britain. The catastrophic consequences of unemployment for trades unions had been demonstrated in 1913-14, when the newly united employers of Dublin crushed a militant and skilfully mobilised Labour movement by judicious employment of 'scabs'. ${ }^{44}$ That experience suggests that, but for the Great War, the great social convulsions of 1917-21 might have been avoided as a result of Labour's continued impotence. Yet collective behaviour is affected not only by economic rationality, but by emotions such as indignation, pride, and fraternal loyalty. As the war showed, by inducing over 200,000 Irishmen to risk their lives with only trifling material inducements, such emotions often prevail over rational calculation. It is probable that the sense of collective grievance among Irish

43 'Permanent' emigrants (as classified by the Registrar-General) were those preparing to settle outside Ireland for at least a year, many of whom would in fact have returned. Though on 'temporary' contracts, many servicemen and munition workers would never return to Ireland after the war.

${ }^{44}$ Padraig Yeates, Lockout: Dublin, 1913 (Dublin, 2000). 
workers would have generated further class conflict even in the teeth of heavy unemployment, the grievance being intensified by the very factor inhibiting its effective expression. Studies of trades unionism in twentieth-century Britain have indicated no clear correlation between the proportion of the workforce unemployed and the frequency of strikes. ${ }^{45}$ The war rendered industrial struggle more practicable but less desirable, since most workers accepted that their duty was to support the war effort. In the absence of war, industrial struggle would have seemed more desirable but less practicable.

The fate of feminism in a warless Ireland is equally conjectural. In addition to extending female participation in the paid workforce, the war mobilised thousands of Irishwomen in voluntary work. ${ }^{46}$ In the absence of war, fewer women would have undergone these potentially liberating experiences, while the persistence of heavy male unemployment would have restricted female infiltration of all sectors of employment. As in Britain, these negative factors must be balanced against the war's consequences for feminist organisation and mobilisation. Most suffragist bodies in Britain adopted the strategy of the major trades unions by remobilising their members behind the war effort. In Ireland, feminist agitation was likewise suspended. Influential bodies such as the Irish Women's Suffrage Federation and the Irish Women's Suffrage and Local Government Association followed the example of Christabel Pankhurst by devoting themselves to patriotic propaganda and voluntary war work. By contrast, the more militant Irish Women's Franchise League suspended its agitation in order to subvert the war effort, many of its members transferring their enthusiasm to Sinn Féin or Cumann na mBan. The war therefore tended to extend female involvement in public life, while curtailing the public pursuit of feminist causes.

In Dangerfield's classic formulation, the outbreak of war suspended the menace of three factors which had already undermined the Liberal consensus: industrial conflict, suffragism, and the conflict over Home Rule. ${ }^{47}$ The counterfactual history of Irish political struggle is particularly uncertain, since it concerns several contending popular movements as well as an external government. In the absence of a declaration of war in August 1914, the wartime compromise of suspended Home Rule would have been impracticable. Instead, several alternative outcomes might have followed the passage of the unamended Act through the Commons in three successive parliamentary sessions, and the failure to achieve a compromise through the Buckingham Palace Conference. These options included the application by Asquith's government of Home Rule for thirty-two counties; the imposition of an amended but unagreed settlement offering some local autonomy for all or part of Ulster; or the government's dismissal or resignation, followed by electoral defeat, the abandonment of Home Rule, and a renewed attempt to maintain the undivided Union.

Our assessment of the implications of each outcome depends on the credence given to the rhetorical claims of the protagonists. Nationalists and unionists accused each other of bluff, while being nervous enough to maintain

45 J. W. Durcan, W. E. J. McCarthy, and G. P. Redman, Strikes in post-war Britain: a study of stoppages of work due to industrial disputes, 1946-73 (London, 1983).

46 Margaret Downes, 'The civilian voluntary aid effort' in Fitzpatrick, Ireland and the First World War, pp 27-37; Eileen Reilly, 'Women and voluntary war work' in Gregory and Pašeta, Ireland and the Great War, pp 49-72; Clear, 'Fewer ladies', pp 161-4.

47 George Dangerfield, The strange death of liberal England (London, 1935). 
substantial private armies in anticipation of sectarian civil war as well as possible confrontation with the Crown forces. The impressive performance of the Irish Volunteers in 1916, involving less than a hundredth of the force available in August 1914, suggests that some nationalists were indeed prepared to defend their perceived entitlement to self-government through use of arms. A unionist electoral victory, followed by abandonment of Home Rule, would surely have provoked a nationalist rebellion with far broader public support than in 1916, and with still more catastrophic consequences for Anglo-Irish relations. The Ulster Volunteer Force, smaller but better armed and organised, was undeniably determined and prepared to use force against the application of Home Rule to Ulster. Its elaborate and systematic contingency plans for immobilising the police, and placing administrative control of the province under a provisional government, confute the contemporary nationalist fantasy that Ulster 'loyalists' would never use violence against the forces of the revered Crown.

It follows that any attempt to enforce an unagreed constitutional settlement would have provoked armed resistance from at least one Irish party, accompanied by the convocation of a revolutionary government in either Belfast or Dublin. The initial collisions between government forces and the Volunteers would rapidly have broadened into civil conflict, at least in Ulster, where both private armies were most densely organised. As in 1920-2, when sections of the Ulster Volunteer Force were effectively reconstituted as a special constabulary, the beleaguered government would doubtless have embodied, or colluded with, any well-disposed partisan militia in its struggle against hostile militias. This analysis suggests that armed rebellion, with the probable consequence of civil war, was inevitable in the absence of a wartime political truce. If so, the major military consequence of the war was to postpone sectarian civil war until 1920-2, with a further and even bloodier instalment after 1969. Had that civil war occurred in 1914, instead of being shaped by the creation of a separate state in Northern Ireland, it would presumably have engulfed a far larger region with horrific consequences for the southern Protestant minority.

There was, however, a fourth possible outcome to the crisis of 1914, underpinning an alternative history which continues to tantalise historians of what might have been. Despite the collapse of negotiation in July 1914, it is likely that the practical implementation of Home Rule would have been further postponed in order to allow further negotiation. The provisions of the Act allowed about a year's grace between its passing and its implementation, even without a suspensory measure. ${ }^{48}$ What form of compromise might have been accepted by both nationalists and unionists in the absence of war? Of all the options, the least plausible was that actually imposed in 1920-2 (Home Rule for six counties, followed by Dominion status for twenty-six counties). In August 1914, no prominent unionist had yet publicly countenanced Home Rule for Ulster under unionist control, and no influential nationalist had publicly accepted the principle of long-term partition. Lloyd George's

48 Section 49 of the Government of Ireland Act (4 \& 5 Geo. 5, cap. 90) required that the Irish Parliament be summoned to meet within four months of the 'appointed day' (the first Tuesday in the eighth month after the passing of the Act), while the implementation of other elements of the settlement could be varied by Order in Council within a range of seven months before and after the 'appointed day'. 
eventual 'settlement', while imperilling both northern Catholics and southern Protestants, proved workable because it gave local power within a governable territory to each major party. It seems improbable that either Irish protagonist, in 1914, could have afforded to trade the freedom of minorities for the power of majorities as their war-weary successors did in 1920-2. Without the wreckage wrought by republican rebels in the South and sectarian factions in the North, public acquiescence in this dual surrender of principles could scarcely have been secured. ${ }^{49}$

If the partition of Ireland into two somewhat autonomous states was not yet a practical option in 1914, other possible compromises had already been widely discussed: permanent or temporary exclusion of all or part of Ulster from Home Rule; Home Rule within Home Rule, entailing the dual parliamentary subordination of Belfast to Dublin and London; or some form of federal settlement. Innumerable variations of these models had already failed to achieve consensus, and further negotiation on such lines could not long have been sustained after a warless August. This supposition is confirmed by the breakdown of negotiations after the Easter Rising, despite the extra urgency with which both constitutionalists and unionists sought a compromise in order to negate the growing separatist challenge. It follows that armed conflict would indeed have erupted in Ireland in the absence of external war, but that one of these compromises might eventually have been accepted in order to put an end to the conflict. In short, both civil war and a workable settlement might have been achieved more rapidly but for the disturbing influence of the Great War. The shape of both the armed conflict and the eventual settlement would have differed radically from those which followed after the Easter Rising, itself an event almost inconceivable except in the context of a wider war.

These speculations suggest that no single counterfactual history of a warless Ireland is defensible. Whereas demographic factors point towards an urban focus for unrest, the absence of war-generated prosperity might have exacerbated rural discontent. Without war, the bargaining position of industrial workers and of women would have been weaker, yet the organisations asserting their collective interests would not have been enfeebled by redirection into patriotic enterprises. Had no war broken out in August 1914, Ulster and perhaps most of Ireland would soon have been engulfed in armed conflict between official and private armies, and subsequently between sectarian factions. These conflicts would probably have been resolved (if at all) along the lines of compromise discussed up to 1914, rather than through partition. In the absence of war, Ireland in 1918 might have been an even darker and more fractured country than the ravaged states that emerged from conflagration after 1922. The Great War brought mixed blessings as well as unmistakable horrors to Ireland and those who lived there. Its full impact can only be understood by trying, as Roy Foster has urged, to devise 'a historical strategy that recaptures uncertainties and thereby unlocks contemporary mentalities'. Through counterfactual history, as well as biographical and local studies, we may try 'to recapture what the future looked like' to those locked in Ireland's pre-war past. ${ }^{50}$

49 For development of these themes, see David Fitzpatrick, The two Irelands, 1912-1939 (Oxford, 1998).

${ }^{50}$ R. E. Foster, The Irish story: telling tales and making it up in Ireland (London, 2001), pp 20-1. 